\title{
Seasonal Variation in Essential Oils Composition and the Biological and Pharmaceutical Protective Effects of Mentha longifolia Leaves Grown in Tunisia
}

\author{
Karama Zouari-Bouassida $\left(\mathbb{D},{ }^{1}\right.$ Mohamed Trigui $\left(\mathbb{D},{ }^{1}\right.$ Samar Makni, ${ }^{1}$ \\ Lobna Jlaiel, ${ }^{2}$ and Slim Tounsi $\mathbb{D}^{1}$ \\ ${ }^{1}$ Laboratory of Biopesticides, Center of Biotechnology of Sfax, University of Sfax, P.O. Box 1177, 3018 Sfax, Tunisia \\ ${ }^{2}$ Analysis Department of the Center of Biotechnology of Sfax, University of Sfax, P.O. Box 1177, 3018 Sfax, Tunisia
}

Correspondence should be addressed to Karama Zouari-Bouassida; k.bouassidazouari@yahoo.fr

Received 16 July 2018; Accepted 6 November 2018; Published 9 December 2018

Academic Editor: Antonio Teixeira

Copyright ( $) 2018$ Karama Zouari-Bouassida et al. This is an open access article distributed under the Creative Commons Attribution License, which permits unrestricted use, distribution, and reproduction in any medium, provided the original work is properly cited.

\begin{abstract}
This research assessed the seasonal variation of the chemical composition and antibacterial and anticholinesterase activities of essential oils extracted from $M$. longifolia leaves. The leaves organic fractions were also investigated for their biological activities and pharmacological functions. The essential oil highest yield was recorded in the spring season. Pulegone (26.92\%), 1.8 cineole $(21.3 \%)$, and L-menthone (10.66 \%) were determined as its major compounds in the winter season. In the spring oil, the main components were pulegone (38.2\%) and oleic and palmitic acids ( $23.79 \%$ and $15.26 \%$, respectively). Oxygenated monoterpenes were predominant in the two analyzed samples. The tested oils and organic extracts exhibited promising antibacterial effects against all of the tested bacterial strains. Thanks to its richness in phenolic and flavonoid compounds, the ethyl acetate fraction $(\mathrm{Ml} \mathrm{EtOAcF})$ displayed the most active $\mathrm{DPPH}$ scavenging ability $\left(\mathrm{IC}_{50}=12.64 \mu \mathrm{g} / \mathrm{ml}\right)$ and an interesting $\beta$-carotene bleaching inhibition $\left(\mathrm{IC}_{50}=34.75 \mu \mathrm{g} / \mathrm{ml}\right)$ making it a potential candidate for anti-inflammatory evaluation on rats. This evaluation evidenced that $M$. longifolia pretreated rats showed a marked decrease in paw oedema and inflammatory cells. Additionally, a remarkable acetylcholinesterase inhibitory activity of the $\mathrm{Ml} \mathrm{EtOAcF}\left(\mathrm{IC}_{50}=12.3 \mu \mathrm{g} / \mathrm{ml}\right)$ and essential oils were also observed suggesting their neuroprotective property against Alzheimer's disease. Moreover, it was found that its activity level was season dependent. Our investigation, therefore, clearly revealed the medicinal characteristics of $M$. longifolia leave indicating their potential uses for natural remedies.
\end{abstract}

\section{Introduction}

Oxidative stress is one of the biological processes involved in the development of chronic diseases like inflammation, atherosclerosis, cancer, diabetes, and neurodegenerative diseases including Alzheimer [1]. Antioxidant molecules play a protective role against damage induced by free radicals and they are crucial in maintaining good human health [2]. Medicinal plants have been used in developing countries as alternative treatments to solve health problems. In recent years, scientists have focused remarkably on seeking natural antioxidant molecules to protect cells and tissues from biological damage induced by oxidative stress. Plant secondary metabolites, especially polyphenols, are naturally occurring compounds largely distributed in the plant extracts [3]. They have been reported to have potential protective roles against several human diseases and disorders, thanks to their antioxidant activity and enzyme-inhibitory capacity [4]. Previous studies highlighted that the anti-inflammatory efficiency has been attributed to these natural antioxidant compounds, suggesting them to be a new alternative against cellular injury induced by oxidative stress such as inflammation $[5,6]$.

Additionally, phenolic compound activities, acting as inhibitors of acetylcholinesterase (AChE), have also been revealed and were closely correlated with their structure and could be used as effective and safe Alzheimer's disease (AD) 
therapy [7]. AD results from decreasing cholinergic functions in the brain by rapid and excessive hydrolysis of acetylcholine [8]. Therefore, one of the most promising strategies for the treatment of this disease was to inhibit the AChE. Investigations of plants with an anticholinesterase action have therefore gained attention in this field. Many secondary plant metabolites have been shown to exert an anti-AChE activity [9] and therefore can be used as novel natural drugs reducing side effects and providing numerous beneficial effects on human health. Various studies are currently carried out in order to find adequate phytocompounds which can be used as activators of antioxidative defence enzyme systems to delay or suppress the cellular damage in biological systems $[10,11]$.

Thus, natural products from plants having antioxidant capacities might be a promising alternative to generate new multitargeting bioactive compounds.

The Tunisian flora is characterized by a large diversity of aromatic and medicinal plants. M. longifolia L is a perennial and aromatic herb which belongs to Lamiaceae and commonly known as "hbak" in Tunisia. Total decoction of M. longifolia L. has been traditionally used for the treatment of many respiratory disorders such as cold, bronchitis, and sinusitis as well as gastrointestinal disorders such as stomach problems, diarrhea, and abdominal pain [12]. The M. longifolia essential oil has also been scientifically known for its analgesic, antimicrobial, antioxidant, and antiplatelet properties [13-15].

Previous studies on the chemical composition and medicinal properties of $M$. longifolia have mainly focused on its crude extract and essential oil, but only few reports have dealt with the organic fractions of the plant and searched for their anti-inflammatory and anticholinesterase activities as well. The present study aimed mainly to (i) assess the essential oil content and composition of $M$. longifolia with regard to time of its leaves collection; (ii) investigate the influence of the seasonal variation on the antioxidant, antibacterial, anticholinesterase capacities of $M$. longifolia leave essential oils; (iii) explore the in vivo anti-inflammatory efficiency of the most active fraction, $\mathrm{Ml} \mathrm{EtOAcF}$, with reference to its phenolic compounds richness and antioxidant and antimicrobial effects.

\section{Materials and Methods}

2.1. Essential Oil Extraction and Chemical Analysis. M. longifolia fresh leaves were harvested from Jelma Sidi Bouzid (Tunisia, latitude $35.36^{\circ}$ and longitude $9.38^{\circ}$ ). Plant samples were collected twice: during spring (April-May) and winter at the full ripening (October-November). The plant specimen was authenticated by Professor Mohamed Chaieb, and a voucher sample was kept at the Biopesticides Laboratory Herbarium of the Centre of Biotechnology of Sfax under the code number LBPes 04.

The essential analysed oils in this study were extracted by hydrodistillation of $M$. longifolia fresh leaves (100g) for 3 h using a Clevenger-type apparatus. The essential oils were performed in triplicate for each oil sample. The oil was extracted with dichloromethane $(3 \times 50 \mathrm{ml})$ and dried with anhydrous $\mathrm{Na}_{2} \mathrm{SO}_{4}$. For yield determination, the solvent was evaporated using a rotavapory vacuum evaporator (BUCHI R-200), the yields were calculated according to dry weight of the plant material. The resulting samples were transferred to opaque glass and stored at $4^{\circ} \mathrm{C}$ during the experimental period. The M. longifolia essential oil was diluted in $n$-Hexane for gas chromatography-mass spectrometry analysis (GCMS).

2.2. Gas Chromatography-Mass Spectrometry (GC-MS) Anal$y$ sis. GC-MS analysis of the M. longifolia essential oil was performed with an Agilent 6890N Network GC system (Agilent Technologies). The system was equipped with an HP-5 MS column having $30 \mathrm{~m} \times 0.25 \mathrm{~mm}$ i.d. $\times 0.25 \mu \mathrm{m}$ film as dimensions. The used system was coupled to a mass selective detector and the carrier gas was Helium. The GC oven temperature started at $40^{\circ} \mathrm{C}$ and was held at $100^{\circ} \mathrm{C}$ for $1 \mathrm{~min}$ and then programmed to rise from 100 to $280^{\circ} \mathrm{C}$ at a rate of $5^{\circ} \mathrm{C} / \mathrm{min}$. The identification of essential oil constituents was performed by comparing their kovats index and mass spectra with those of the authentic standards stored on the Wiley Registry of Mass Spectral Data 7th edition (Agilent Technologies, Inc.) and National Institute of Standards and Technology 05 MS (NIST) library data.

2.3. Preparation of M. longifolia Leaf Extracts. The M. longifolia powdered leaves (from winter crops) were crumbled into small parts using a blender and were macerated three times in ethanol-water $(8: 2, \mathrm{v} / \mathrm{v})$. The resulting extract was filtered and ethanol was evaporated and lyophilized to yield the hydroalcoholic crude extract $\left(\mathrm{Ml} \mathrm{EtOH}-\mathrm{H}_{2} \mathrm{OE}\right)$. The dried hydroalcoholic crude extract $(23 \mathrm{~g})$ was sequentially partitioned with $\mathrm{n}$-hexane $(3 \times 350 \mathrm{ml})$ and ethyl acetate $(3$ $\times 350 \mathrm{ml}$ ). The filtered solution was evaporated at reduced pressure (Rotary Evaporator Buchi R-200, Switzerland) and the remaining aqueous layer was lyophilized to give the water fraction. The resulting three fractions were evaporated under vacuum to dryness to give the hexane ( $\mathrm{Ml} \mathrm{HexF})$, the ethyl acetate ( $\mathrm{Ml}$ EtOAcF), and water (Ml WF) fractions. The stock solutions were kept at $4^{\circ} \mathrm{C}$ in the dark until tested and analyzed.

2.4. Determination of Total Phenols (TPC). The TPC in extracts was determined according to the Folin-Ciocalteu procedure with slight modifications [16]. A calibration curve was constructed using gallic acid and the results were expressed as mg gallic acid equivalent (GAE)/g. Tests were performed in triplicate for each extract.

2.5. Determination of Total Flavonoids (TF). The assay was performed spectrophotometrically following the procedure described by Quettier-Deleu et al. [17] based on the formation of a complex flavonoid-aluminium, having a maximum absorption at $430 \mathrm{~nm}$. The flavonoid content was expressed in $\mathrm{mg}$ of quercetin equivalent per gram of dry plant extract (mg QE/g).

\subsection{In Vitro Antioxidant Assay}

2.6.1. DPPH Antiradical Activity. The capacity of M. longifolia leave extracts (essential oil; hydroethanolic extract and 
its fractions) to scavenge the free-radical 2, 2-diphenyl-1picrylhydrazyl (DPPH) was determined according to the method described by Trigui et al. [18] with slight modifications. In Brief, a dosage of $50 \mu \mathrm{l}$ of the extract assayed at different concentrations was added to $2 \mathrm{ml}$ of a DPPH solution $(0.04 \mathrm{~g} / \mathrm{l}$ in methanol). The mixtures were incubated for $30 \mathrm{~min}$ in the dark at room temperature.

The DPPH radical reduction was evaluated spectrophotometrically by continuous monitoring of the absorption decrease at $517 \mathrm{~nm}$. Ascorbic acid was used as a positive control. The DPPH scavenging effect percentage was calculated using the following formulae:

$$
\left[\frac{1-\text { Aextract }}{\text { ADPPH }}\right] \times 100
$$

where Aextract is the absorbance of the solution when an extract is added and ADPPH is the DPPH solution absorbance. The $\mathrm{IC}_{50}$ was then calculated (the fraction concentration that inhibits $50 \%$ of free radicals).

2.6.2. $\beta$-Carotene Bleaching Assay. The ability of the $M$. longifolia leave extracts to prevent the bleaching of $\beta$-carotene was assessed as previously described by Trigui et al. [18]. A solution of $\beta$-carotene/ linoleic acid was prepared by dissolving $0.2 \mathrm{mg}$ of $\beta$-carotene, $20 \mu \mathrm{l}$ of linoleic acid, and $200 \mathrm{mg}$ of Tween $40 \mathrm{in} 1 \mathrm{ml}$ of chloroform. After chloroform evaporation under reduced pressure at $40^{\circ} \mathrm{C}, 50 \mathrm{ml}$ of oxygen bubbled water was slowly added to the residue and the resulting mixture was vigorously shaken. Aliquots $(5 \mathrm{ml})$ of the obtained emulsion was added to a tube containing 500 $\mu \mathrm{l}$ of each extract and kept in a water bath at $50^{\circ} \mathrm{C}$ for $120 \mathrm{~min}$ before measuring the absorbance at $470 \mathrm{~nm}$. The butylated hydroxytoluene (BHT) was used as the reference. The antioxidant activity is expressed in terms of percent inhibition using the following formula:

$$
\text { Inhibition } \%=\left[\frac{A \beta-\text { carotene after } 2 \text { h assay }}{A \text { initial } \beta-\text { carotene }}\right] \times 100
$$

where $A \beta$-carotene after $2 \mathrm{~h}$ assay and $\mathrm{A}$ initial $\beta$-carotene are the absorbance of $\beta$-carotene after $2 \mathrm{~h}$ assay and the absorbance of $\beta$-carotene at the beginning of the experiments, respectively. The necessary antioxidant concentration to reduce $50 \%$ of the absorbance (IC50) was determined. Tests were performed in triplicate for each extract.

2.7. In Vitro Antibacterial Activity. Different microorganisms, including Gram-positive bacteria (Bacillus subtilis ATCC 6633, Bacillus cereus ATCC14579, Staphylococcus aureus ATCC 25923, Staphylococcus epidermidis ATCC 12228, Enterococcus faecalis ATCC 29212, Micrococcus luteus ATCC 1880, and Listeria monocytogenes 2132) and Gram-negative bacteria (Salmonella enteritidis and Klebsiella pneumoniae ATCC 10031) were used for testing the antibacterial activities of M. longifolia essential oils and fractions. Mueller-Hinton agar (MH) (Oxoid Ltd., UK) was used for the bacterial strains cultivation for 24 hours at the appropriated temperature. The agar-well diffusion assay was employed for this purpose [19]. The minimum inhibitory concentrations (MICs) were determined using the microdilution bioassay in 96well microplates according to Eloff et al. [20] with minor modifications. Gentamicin was used as positive control. All tests were carried out in triplicates.

2.8. In Vitro Anticholinesterase Activity. The acetylcholinesterase (AChE) inhibitory activity was carried out using the spectrophotometric method developed by Mata et al. [21] using electric eel acetylcholinesterase (EC 3.1.1.7, type VS). The absorbance of the mixture was measured at 405 $\mathrm{nm}$. Acetylthiocholine iodide (AChI) was employed as substrate of the reaction and 5, 5'-Dithio-bis-2-nitrobenzoic acid (DTNB) was used for the measurement of the anticholinesterase activity. The galanthamine. $\mathrm{HBr}$ was used as positive control. The obtained results were expressed as $\mathrm{IC}_{50}$ values calculated as the extracts concentration that can produce $50 \%$ inhibition activity again cholinesterase.

\subsection{In Vivo Anti-Inflammatory Test}

2.9.1. Animals. Wistar rats with body masses around 175 $\mathrm{g}$ were obtained from the Veterinary Research Institute (Sfax, Tunisia). The animals were caged under environmental conditions of humidity, temperature and dark/light cycle with free access to diet and water. The animal study was performed in accordance with the European Community guidelines (EEC directive of 1986; 86/609/EEC) for the care and use of laboratory animals in scientific research and approved by the Medical Institutional Animal Ethics Committee (Directive 2001-2133) issued by the University of Sfax Tunisia.

2.9.2. Acute Toxicity Study. The acute toxicity study was performed according to the World Health Organization recommendations (2000) with some modifications. Healthy rats $(175 \mathrm{~g})$ were randomly divided into five groups $(\mathrm{n}=10)$. The control group (group I) received only a solution of Tween-80 (3\%), while groups II, III, IV and V were treated with $\mathrm{Ml} \mathrm{EtOAcF}$ at doses of 100, 200, 400, and $800 \mathrm{mg} / \mathrm{kg}$ body weight, respectively. Following the fasting period, the graded doses of Ml EtOAcF dissolved in Tween-80 (3\%), were administered orally by gavage. The animals were maintained on standard animal diet and water. All animals were daily observed for behavioral pattern, body weight, and physical appearance changes and checked for mortality during the 2week observation period.

\subsubsection{Anti-Inflammatory Test: Carrageenan Induced Paw} Oedema. The rats were split into four groups $(n=10)$ pretreated, respectively, with $1 \mathrm{ml} / \mathrm{kg}$ of sterile saline solution (control group), carrageenan $1 \%$ (control group), $10 \mathrm{mg} / \mathrm{kg}$ BW of indomethacin as a standard group, and $200 \mathrm{mg} / \mathrm{kg}$ of $\mathrm{Ml} \mathrm{EtOAcF} \mathrm{[22].} \mathrm{Paw} \mathrm{oedema} \mathrm{was} \mathrm{induced} \mathrm{[23]} \mathrm{by} \mathrm{subcuta-}$ neous injection of $50 \mu \mathrm{l}$ of $1 \% \mathrm{w} / \mathrm{v}$ carrageenan solution (type IV Sigma Chemical Company, USA) into the foot pad of the right hind paw after one hour of intraperitoneal injection of plant extract and drug. The paw oedema thickness was measured at hourly interval (from 0 hour up to 5 hours) using a caliper and compared with the control group [24]. The drug 
efficiency and carrageenan induced oedema were estimated using the following formula:

$$
\% \text { inhibition oedema }=\frac{T-T 0}{T} \times 100
$$

where T represents the paw thickness in the control group and T0 the paw oedema thickness in the test compound treated group.

Five hours after the carrageenan administration, the animals were anesthetized and the biopsies from the subplantar muscles of all groups of rats were collected for the paws histological examination.

2.10. Statistical Analysis. Data were expressed as mean values \pm standard deviation (SD). A statistical significance comparison between groups was accomplished using the SPSS version 20.

The mean differences between the different groups were assessed by Duncan and Tukey's post hoc tests and compared using one way analysis of variance (ANOVA). Differences were considered significant at $P<0.05$.

\section{Results and Discussion}

3.1. Seasonal Variation in M. longifolia Essential Oil. The oil yield-revealed data are shown in Table 1. The largest amount of oil was found during the winter season corresponding to the flowering stage $(2.5 \%)$ whereas the $M$. longifolia oil content decreased significantly $(P<0.05)$ in the spring season to reach $0.5 \%$. The results revealed that essential oil accumulation in M. longifolia appears to be metabolically regulated during vegetative and flowering stages of crop growth. Such results were expected as the flowering stage is well known to be the most suitable for essential oil extraction compared to vegetative stage [25] and were in agreement with other research findings reporting a maximum essential oil yield during flowering stage [26]. It was also shown by Hussain et al. [27] that many tested Mentha species revealed higher essential oil yield when the plants were in full bloom than when they reached the end of their growth cycle. The climatic factors variability such as temperature, total duration of exposure to sun, and precipitation could directly influence the oil yield during the two harvesting seasons [28, 29]. It was reported that the temperature influenced the oil yield of $O$. basilicum with the highest yields in the winter season [30].

The mean percentage composition of total identified compounds of essential oils collected through the two seasons and used in bioassays are presented in Table 2. A total of eighteen and sixteen compounds, accounting for 89.91 and $97.95 \%$ of the total content, were identified in the essential oils obtained from winter and spring leaves, respectively. The oxygenated monoterpenes fraction dominated the two essential oils samples.

The content of oxygenated monoterpenes in the essential oils was higher during the winter (81.19\%) and lower during the spring (53.48\%). Apart from the similarity in the major compound, the oils collected in winter and spring showed notably quantitative differences. In the winter crops, the prominent components were pulegone (26.92\%), Lmenthone $(10.66 \%)$, and 1,8 cineole $(21.3 \%)$. However, the major constituents in the spring oil were found to be pulegone $(38.2 \%)$ and fatty acids. This oil harbors also menthone (4.68\%), menthol (4.29\%), and 1,8 cineole (2.37\%) but with less quantities. Fatty acids, not detectable in the winter oil, were represented mainly by oleic acid (23.79\%) and palmitic acid (15.26\%) and to a lesser extent by linoleic acid (3.27\%) in the postflowering stage essential oil. Moreover, the tested M. longifolia essential oils contained significant amounts of several minor constituents, as seen in Table 2, including sesquiterpene hydrocarbons, oxygenated sesquiterpenes, and esters.

The variation in the composition of the M. longifolia essential oils investigated in this study was quantitatively significant $(P<0.05)$. Most fluctuations in the essential oil components includes oxygenated monoterpenes, namely, pulegone (26.92-38.2\%), 1, 8 cineole (2.37-21.3\%), L- Menthone (4.68-10.66 \%), $\beta$ pinene $(0.24-1.22), \alpha$ pinene $(0.12-0.93 \%)$, cis iso-pulegone (0-0.86 \%), and piperitenone (1.18-9.62\%) from spring and winter, respectively. The yield of most of the compounds was higher in the flowering stage (winter), while pulegone was found to be high in the spring plant collection.

Our findings are in line with those of Gazim et al. [31], who stated essential oil composition variation obtained from Tetradenia riparia (Lamiaceae) leaves at different seasons. The oxygenated monoterpenes and oxygenated sesquiterpenes contents were high during the winter and low during the spring-summer.

The seasonal variations in content and chemical composition of $M$. longifolia essential oil across countries have been attributed to environmental factors (climate/weather, soil/nutrition) that can influence the regulation of the essential oil biosynthesis [32]. Just like our results, previous investigations have demonstrated that the harvesting season can alter the chemical composition of the essential oils of $M$. longifolia [30].

Thus, based on these results and previous works we can conclude that the ingredients of M. longifolia essential oil revealed a variation in its constituents depending on geographical and environmental factors and harvest time. Indeed, the adaptive metabolism of the plant influences the quality, the quantity and the chemical composition of the plant essential oil and could probably contribute to create a unique and specific chemical composition.

Several previous reports from the literature show the qualitative and the quantitative analyses of Mentha longifolia essential oil from different countries [33-35].

3.2. Total Phenolics (TPC) and Flavonoids (TFC). The quantitative estimation of TPC of the M. longifolia leave extracts (Table 1) showed that they are upper than their TFC amounts. The content of these secondary metabolites depends on the type of solvent used for the extraction with varying polarity.

The $\mathrm{MlEtAOcF}$ was found to contain the highest amount of phenolics (99.72 $\pm 1.26 \mathrm{mg} \mathrm{GAE} / \mathrm{g})$ compared to $\mathrm{Ml} \mathrm{EtOH}$ $\mathrm{H}_{2} \mathrm{O}$ extract $(59.25 \pm 0.38 \mathrm{mg} \mathrm{GAE} / \mathrm{g})$ and $\mathrm{Ml} \mathrm{WF}(45.25$ $\pm 0.87 \mathrm{mg} \mathrm{GAE} / \mathrm{g})$. The $\mathrm{Ml} \mathrm{EtAOcF}$ also contained the 
TABLE 1: Yields extracts, amounts of total flavonoids, total phenolic compounds, and determined $\mathrm{IC}_{50}$ values of the DPPH free radical scavenging assay of M. longifolia leave extracts and essential oil. Ascorbic acid was used as positive control.

\begin{tabular}{|c|c|c|c|c|c|}
\hline Extracts & Yield (\%) & $\begin{array}{c}\text { TPC } \\
\text { mg GAE/g }\end{array}$ & $\begin{array}{c}\text { TF } \\
\mathrm{mg} \mathrm{QE} / \mathrm{g}\end{array}$ & $\begin{array}{c}\text { DPPH } \\
\mathrm{IC}_{50}(\mu \mathrm{g} / \mathrm{ml})\end{array}$ & $\begin{array}{c}\beta \text { carotene } \\
\mathrm{IC}_{50}(\mu \mathrm{g} / \mathrm{ml})\end{array}$ \\
\hline $\mathrm{Ml} \mathrm{EtOH}-\mathrm{H}_{2} \mathrm{OE}$ & 12.46 & $59.25 \pm 0.38$ & $18.23 \pm 0.35$ & $16.23 \pm 1.60$ & $66.75 \pm 0.57$ \\
\hline Ml HexF & 7.35 & nd & nd & $>1000$ & $>1000$ \\
\hline Ml EtAOcF & 2.5 & $99.72 \pm 1.26$ & $20.85 \pm 0.94$ & $12.64 \pm 0.21$ & $34.75 \pm 0.76$ \\
\hline Ml WF & 2.61 & $45.25 \pm 0.87$ & $10.75 \pm 0.47$ & $47.71 \pm 0.43$ & $56.31 \pm 0.67$ \\
\hline $\mathrm{EO}_{\mathrm{s}}-\mathrm{EO}_{\mathrm{w}}$ & $0.5-2.5$ & - & - & $>100$ & $>100$ \\
\hline Ascorbic acid & - & - & - & 3.50 & - \\
\hline
\end{tabular}

TPC: total phenolic content; TF: flavonoid content.

$\mathrm{mg}$ GAE /g: mg of gallic acid equivalent per $\mathrm{g}$ of dry plant extract.

$\mathrm{mg} \mathrm{QE} / \mathrm{g}$ : $\mathrm{mg}$ of quercetin equivalent per g of dry plant extract.

$\mathrm{IC}_{50}(\mu \mathrm{g} / \mathrm{ml})$ : the $\mathrm{IC}_{50}$ values corresponding to the amount of extract required to scavenge $50 \%$ of radicals present in the reaction mixture.

nd: not detected.

$\mathrm{EO}_{\mathbf{w}}$ : essential oil extracted at winter season; $\mathrm{EO}_{\mathbf{s}}$ : spring essential oil.

TABLE 2: Seasonal variation in content and chemical composition of essential oils from leaves of M. longifolia.

\begin{tabular}{|c|c|c|c|c|}
\hline \multirow{2}{*}{ Component $^{\mathrm{A}}$} & \multirow{2}{*}{$\operatorname{Rt}(\min )^{B}$} & \multirow{2}{*}{$\mathrm{KI}^{\mathrm{C}}$} & \multicolumn{2}{|c|}{$\%$ Area } \\
\hline & & & Spring & Winter \\
\hline \multicolumn{5}{|c|}{ Monoterpene hydrocarbons } \\
\hline$\alpha$-pinene & 8.557 & 941 & $0.12 \pm 0.008^{\mathrm{b}}$ & $0.93 \pm 0.02^{\mathrm{a}}$ \\
\hline camphene & 9.764 & 953 & $0.18 \pm 0.03^{\mathrm{b}}$ & $0.41 \pm 0.008^{\mathrm{a}}$ \\
\hline$\beta$-pinene & 9.827 & 978 & $0.24 \pm 0.02^{\mathrm{b}}$ & $1.22 \pm 0.05^{\mathrm{a}}$ \\
\hline \multicolumn{5}{|c|}{ Oxygenated monoterpenes } \\
\hline 1,8 cineole & 11.492 & 1030 & $2.37 \pm 0.16^{\mathrm{b}}$ & $21.3 \pm 0.24^{\mathrm{a}}$ \\
\hline L-menthone & 15.206 & 1152 & $4.68 \pm 0.2^{\mathrm{b}}$ & $10.66 \pm 0.1^{\mathrm{a}}$ \\
\hline Iso-menthone & 15.429 & 1163 & $0.16 \pm 0.008^{\mathrm{b}}$ & $8.69 \pm 0.12^{\mathrm{a}}$ \\
\hline Borneol & 15.503 & 1166 & $2.6 \pm 0.02^{\mathrm{a}}$ & $1.87 \pm 0.04^{\mathrm{b}}$ \\
\hline Menthol & 15.801 & 1171 & $4.29 \pm 0.2^{\mathrm{a}}$ & $0^{\mathrm{b}}$ \\
\hline Cis-isopulegone & 17.960 & 1175 & $0^{\mathrm{b}}$ & $0.86 \pm 0.04^{\mathrm{a}}$ \\
\hline Pulegone & 18.349 & 1237 & $38.2 \pm 0.28^{\mathrm{a}}$ & $26.92 \pm 0.53^{\mathrm{b}}$ \\
\hline Piperitone & 19.539 & 1251 & $0^{\mathrm{b}}$ & $0.82 \pm 0.1^{\mathrm{a}}$ \\
\hline Piperitenone & 21.324 & 1340 & $1.18 \pm 0.12^{\mathrm{b}}$ & $9.62 \pm 0.2^{\mathrm{a}}$ \\
\hline cis-Jasmone & 22.406 & 1400 & $0^{\mathrm{b}}$ & $0.45 \pm 0.02^{\mathrm{a}}$ \\
\hline \multicolumn{5}{|c|}{ Sesquiterpene hydrocarbons } \\
\hline trans-Caryophyllene & 22.949 & 1419 & $0.87 \pm 0.04^{\mathrm{b}}$ & $2.7 \pm 0.1^{\mathrm{a}}$ \\
\hline D-germacrene & 24.046 & 1482 & $0.34 \pm 0.008^{\mathrm{a}}$ & $0^{\mathrm{b}}$ \\
\hline gamma.-Cadinene & 25.106 & 1514 & $0^{\mathrm{b}}$ & $0.52 \pm 0.08^{\mathrm{a}}$ \\
\hline d-Cadinene & 27.607 & 1523 & $0.4 \pm 0.006^{\mathrm{a}}$ & $0^{\mathrm{b}}$ \\
\hline delta.-Selinene & 27.857 & 1578 & $0^{\mathrm{b}}$ & $0.30 \pm 0^{\mathrm{a}}$ \\
\hline \multicolumn{5}{|c|}{ Oxygenated sesquiterpenes } \\
\hline alpha.-Humulene & 23.659 & 1454 & $0^{\mathrm{b}}$ & $0.2 \pm 0^{\mathrm{a}}$ \\
\hline alpha.-Cadinol & 28.196 & 1654 & $0^{\mathrm{b}}$ & $2.81 \pm 0.05^{\mathrm{a}}$ \\
\hline \multicolumn{5}{|l|}{ Esters } \\
\hline Geranyl tiglate & 29.260 & 1685 & $0^{\mathrm{b}}$ & $0.24 \pm 0.008^{\mathrm{a}}$ \\
\hline \multicolumn{5}{|l|}{ Fatty Acids } \\
\hline Palmitic acid & 34.729 & 1927 & $15.26 \pm 0.2^{\mathrm{a}}$ & $0^{\mathrm{b}}$ \\
\hline Oleic acid & 38.002 & 2128 & $23.79 \pm 0.5^{\mathrm{a}}$ & $0^{\mathrm{b}}$ \\
\hline Linoleic acid & 38.317 & 2173 & $3.27 \pm 0.01^{\mathrm{a}}$ & $0^{\mathrm{b}}$ \\
\hline Total compound & & & 97.95 & 89.91 \\
\hline
\end{tabular}

\footnotetext{
${ }^{\mathrm{A}}$ Compounds listed in order of elution from a HP-5 MS column.

${ }^{\mathrm{B}}$ Retention time (as minutes).

${ }^{C}$ K.I. Kovats Index on HP-5MS column in reference to n-alkanes.

Values in the same line with different subscript $(\mathrm{a}>\mathrm{b})$ are significantly different within season $(P<0.05)$.
} 
TABLE 3: Acetylcholinesterase inhibition capacity represented by $\mathrm{IC}_{50}(\mu \mathrm{g} / \mathrm{ml})$ of essential oils and organics extracts of Mentha longifolia.

\begin{tabular}{lc}
\hline Extracts & $\begin{array}{c}\text { Percentage of inhibition } \\
\mathbf{I C}_{50}(\boldsymbol{\mu g} / \mathbf{m l})\end{array}$ \\
\hline $\mathrm{Ml} \mathrm{HexF}$ & $934 \pm 42.3^{\mathrm{c}}$ \\
$\mathrm{Ml} \mathrm{EtOH}-\mathrm{H}_{2} \mathrm{OE}$ & $54.25 \pm 1.10^{\mathrm{ab}}$ \\
$\mathrm{Ml} \mathrm{EtOAc-F}$ & $12.3 \pm 0.71^{\mathrm{a}}$ \\
$\mathrm{Ml} \mathrm{WF}$ & $85.68 \pm 3.4^{\mathrm{b}}$ \\
$\mathrm{EO}_{\mathrm{W}}$ & $21.9 \pm 1.14^{\mathrm{a}}$ \\
$\mathrm{EO}_{S}$ & $49.3 \pm 1.56^{\mathrm{ab}}$ \\
Galanthamine $^{*}$ & $19.90 \pm 1.48^{\mathrm{a}}$ \\
\hline
\end{tabular}

Averages \pm SD were obtained from three different experiments. ${ }^{*}$ Standard drug.

EOw: essential oil extracted at winter season; EOs: spring essential oil.

Values in the same line with different subscript $(a>b>c)$ are significantly different within season $(P<0.05)$.

highest flavonoid concentration $(20.85 \pm 0.94 \mathrm{mg} \mathrm{QE} / \mathrm{g}), 2$ fold more than Ml WF with $10.75 \pm 0.47$ (Table 1). The higher TPC and TFC values obtained with the ethyl acetate can be attributed to its good phenolic solubility and the high extraction capacity [36]. These metabolites showed differences in their concentrations in terms of solvents polarities and therefore their solubility which depends on their structures and polymerization degree [37].

3.3. Anticholinesterase Inhibition Assay. The acetylcholinesterase inhibitors are one of the most effective approaches to treat the cognitive symptoms of the Alzheimer's disease (AD). Table 3 shows the antiacetylcholinesterase capacity of essential oils and organic extracts of $M$. longifolia, compared with those of galantamine used as a standard inhibitor.

Based on $\mathrm{IC}_{50}$ values, all the extracts exhibited acetylcholinesterase inhibitory ability in the following order: $\mathrm{Ml}$ EtOAcF > Ml EtOH- $\mathrm{H}_{2} \mathrm{OE}>\mathrm{Ml} \mathrm{WF}>\mathrm{Ml} \mathrm{HexF}$. The uppermost inhibitory activity was recorded with the $\mathrm{Ml}$ EtOAcF $\left(\mathrm{IC}_{50}=12.30 \mu \mathrm{g} / \mathrm{mL}\right)$. Besides, it is clearly shown that AChE inhibitory activity of M. longifolia essential oils varied significantly along their harvesting time. Table 3 shows that the essential oil extracted at the flowering stage (winter crops) exhibited the greatest inhibitory effect against $\mathrm{AChE}$ with an $\mathrm{IC}_{50}$ of $21.9 \mu \mathrm{g} / \mathrm{ml}$. Previous studies reported that the $M$. longifolia leaves essential oils have an acetylcholinesterase inhibitory capacity [38]. However, so far, and to the authors best knowledge, this is the first attempt that explores the seasonal variation of the AChE inhibitory capacity of $M$. longifolia essential oils.

Monoterpenes, reported in M. longifolia essential oils, are known for their biological activities and beneficial effects [39]. Numerous essential oils and their isolated monoterpenes have been investigated for their effects on AChE. It was proven that purified 1.8-cineole, a monoterpene one of the major compounds of winter M. longifolia essential oil, exhibited a potent inhibitory capacity on AChE activity and showed synergistic effect with other constituents [40]. It was reported by Mata et al. [21] that the essential oils of the two Mentha species, M. pulegium and M. spicata, exhibited only moderate $\mathrm{AChE}$ inhibition with an $\mathrm{IC}_{50}$ of 324 and $357 \mu \mathrm{g} / \mathrm{ml}$, respectively. The main components of these oils were pulegone and carvone. These compounds are reported as moderate inhibitors of AChE [41]. According to previous observed data, the AChE inhibition in our case by $M$. longifolia essential oil $\left(\mathrm{IC}_{50}=21.9 \mu \mathrm{g} / \mathrm{ml}\right)$ led to the suggestion that the activity is probably due to the synergistic effects of several components major and minor ones mainly monoterpenoids.

On the other hand, the $\mathrm{Ml} \mathrm{EtOAcF}$ was found to be more effective in the AChE inhibition than essential oils. Differently, Lopez et al. [42] reported an insignificant inhibition of organic extracts of $M$. longifolia on this enzyme.

Plants have been traditionally used to enhance cognitive functions and alleviate other symptoms nowadays associated with Alzheimer's disease [43]. Most of the drugs used in Alzheimer therapy are formed by an enzyme inhibitor, e.g., galanthamine, isolated from the snowdrop extract [44]. There has been a lot of research on the biological effect of plants traditionally used as acetylcholinesterase inhibitors in vitro and also as memory enhancers in vivo $[45,46]$. The great inhibitory effect of $\mathrm{Ml} \mathrm{EtOAcF}$ made us think that this fraction contains neuroprotective phytochemical molecules like phenolic active compounds which could be responsible for the plant potent anti-AChE activity. The AChE inhibition efficacy of Ml EtOAcF observed in this work comes probably from its richness in various effective chemical compounds present in the extract such as phenolic acids and flavonoids, proven to have an inhibitory ability against key enzymes involved in the cholinergic nervous system [47]. The bioactive compounds can act synergistically or individually to induce an AChE inhibitory activity. Further analyses have to be performed to delineate rationally the $\mathrm{Ml} \mathrm{EtOAcF}$ active compound(s).

\subsection{Evaluation of Antioxidant Activity: DPPH and $\beta$ Carotene} Tests. The effect of the different $M$. longifolia organic extracts and essential oils on DPPH radical scavenging capacity was evaluated by the determination of the $\mathrm{IC}_{50}$ values and then compared to the ascorbic acid used as positive control. Based on the $\mathrm{IC}_{50}$ values, the best activities were recorded with $\mathrm{Ml}$ EtOAcF $\left(\mathrm{IC}_{50}=12.64 \mu \mathrm{g} / \mathrm{ml}\right)$, followed by $\mathrm{Ml} \mathrm{EtOH}-\mathrm{H}_{2} \mathrm{OE}$ $\left(\mathrm{IC}_{50}=16.23 \mu \mathrm{g} / \mathrm{ml}\right)$ and then by $\mathrm{Ml} \mathrm{WF}\left(\mathrm{IC}_{50}=47.71 \pm\right.$ $0.43 \mu \mathrm{g} / \mathrm{ml})$. The $\mathrm{Ml} \mathrm{HexF}$ showed a poor radical scavenging activity with an $\mathrm{IC}_{50}$ value more than $1000 \mu \mathrm{g} / \mathrm{ml}$ (Table 1). The $\mathrm{Ml} \mathrm{EtOAcF}$ showed an interesting free-radical scavenging. Ascorbic acid showed a potent antioxidant activity with an $\mathrm{IC}_{50}$ value of $3.5 \mu \mathrm{g} / \mathrm{ml}$ (Table 1).

Both samples of $M$. longifolia essential oil showed a weak $\mathrm{DPPH}$ radical scavenging activity with an $\mathrm{IC}_{50}$ value more than $100 \mu \mathrm{g} / \mathrm{ml}$ when compared to the organic extracts. Our results are in accordance with the findings of Gulluce et al. [48] who reported that M. longifolia methanol extract (obtained at the flowering stage) was more effective in scavenging DPPH free radical than the essential oil. The antiradical efficiency due to a hydrogen atom transferring reaction showed a positive correlation with phenolics content 
$\left(\mathrm{R}^{2}=0.987\right)$ and therefore their implication in M. longifolia antiradical activity.

A wide variation in the antioxidant activity of $M$. longifolia was observed in the literature. Mkaddem et al. [49] showed a moderate $\mathrm{IC}_{50}$ value of essential oil $(>8000 \mathrm{mg} / \mathrm{ml})$ assayed by DPPH. It was also found that the $\mathrm{IC}_{50}$ value of the methanol extract of Turkish $M$. longifolia was in the range of $57.4 \mu \mathrm{g} / \mathrm{ml}$ [48]. In addition, a lower $\mathrm{IC}_{50}$ of methanol extract in the range of $20 \mu \mathrm{g} / \mathrm{ml}$ was obtained by Hajlaoui et al. [50].

All $M$. longifolia organic extracts inhibited the $\beta$-carotene oxidation except for essential oils. The Ml EtOAcF exhibited a strong activity with $\mathrm{IC}_{50}$ values of $34.75 \mu \mathrm{g} / \mathrm{ml}$ compared to those of the essential oils $\left(\mathrm{IC}_{50}>100 \mu \mathrm{g} / \mathrm{ml}\right)$. The inhibition of lipid peroxidation by addition of $M$. longifolia organic extracts could be used to improve the quality and stability of food products. These extracts are able to quenching peroxide radicals and to terminate the peroxidation chain reaction.

These results suggest that $M$. longifolia leaves are promising sources of various bioactive compounds for human health. The results obtained for antioxidant properties in this work are in agreement with earlier results of other authors $[34,48]$.

3.5. Antibacterial Activity. The inhibitory spectra of the essential oils seasonally extracted from $M$. longifolia and its organic extracts were evaluated against nine pathogenic bacteria by the presence or absence of inhibition zones followed by MIC and MBC values measurement (Table 4).

The results indicated that Bacillus subtilis, Bacillus cereus, Staphylococcus aureus, and Enterococcus faecalis were the most sensitive microorganisms to the essential oils. They also exhibited the lowest MIC values varying between 0.078 and $0.156 \mathrm{mg} / \mathrm{ml}, 0.156$ and $0.312 \mathrm{mg} / \mathrm{ml}, 0.312$ and 0.625 $\mathrm{mg} / \mathrm{ml}$, and 0.078 and $0.625 \mathrm{mg} / \mathrm{ml}$, respectively. As shown in Table 4, the $M$. longifolia harvest time affected significantly the inhibitory power of the essential oils $(P<0.05)$. It was found that the activity against Bacillus subtilis, Bacillus cereus, Staphylococcus aureus and Enterococcus faecalis was highest in winter. The potent antibacterial activity of M. longifolia essential oil sample from winter crops could be attributed to its richness in oxygenated monoterpenes (81.19\%). It was reported that an essential oil containing monoterpenoid class compounds showed remarkable antimicrobial activities [51, 52].

Pulegone, 1.8-cineole, and L-menthone were proven to have a potential antibacterial activity. Therefore, the winter essential oil efficiency may be especially related to its richness in such compounds. Pulegone was found to have an antibacterial activity through dissipating the $\mathrm{pH}$ gradient and altering the cell membrane potential [53]. Li et al. [54] reported that 1.8-cineole exhibits strong antibacterial properties that can be attributed to its ability to directly produce alterations on the structure of E. coli, S. enteritidis and S. aureus. Simsek et al. [55] revealed that 1.8-cineole extracted from Eucalyptus essential oils could improve the antimicrobial effects of other antiseptics against some microorganisms such as $S$. aureus, $E$. coli, and E. faecalis. These composites may be able to inhibit synergistically or individually the growth of microorganisms and fight against bacterial infections.

Our results also showed that essential oil samples exhibited high antibacterial activity against all Gram-positive bacteria tested. Among the Gram-negative ones, Salmonella enteritidis showed a lower sensitivity than Klebsiella pneumonia (Table 4). Furthermore, this activity within these strains was not affected by seasonal variation. According to previous reports, Gram-negative bacteria appeared to be less effective in the action of various plant essential oils. This resistance against Gram-negative ones might be related to their highly complex outer membrane which protects them [56]. The Gram-positive bacteria cell membrane may facilitate penetration of the hydrophobic compounds [57]. However, the way the components of essential oil interact to inhibit bacterial growth could be a potential future perspective.

This study showed that the harvest period influences the percentage of chemical constituents of $M$. longifolia essential oil and that the observed essential oil antibacterial characteristics may be related to the oil chemical composition variation.

Among the tested extracts, only $\mathrm{Ml} \mathrm{EtOAcF}$ and $\mathrm{Ml}$ EtOH- $\mathrm{H}_{2} \mathrm{OE}$ exhibited an antibacterial activity. Ml HexF and $\mathrm{Ml} \mathrm{WF}$ remained inactive in the range of the used concentration $(2.5 \mathrm{mg} /$ wells $)$. Active extracts showed a potent antimicrobial activity against both Gram-positive and Gramnegative bacteria. The inhibition zone diameters and MIC values were in the range of $17-27 \mathrm{~mm}$ and $0.039-1.25 \mathrm{mg} / \mathrm{ml}$ for the $\mathrm{MlEtOAcF}$ and $12-20 \mathrm{~mm}$ and $0.078-2.5 \mathrm{mg} / \mathrm{ml}$ for the EtOH-H2OE. The Ml EtOAcF was the most active fraction with the lowest $\mathrm{MBC}$ values ranging from 0.0 .78 to 1.25 $\mathrm{mg} / \mathrm{ml}$, respectively (Table 4 ).

Based on these results, it is possible to conclude that $\mathrm{Ml}$ EtOAcF has a stronger and broad spectrum of antibacterial activity compared to the essential oil and EtOH- $\mathrm{H}_{2} \mathrm{OE}$. The observed differences in the inhibition zones within pathogenic bacteria could probably be due to cell membrane permeability or other genetic factors.

Furthermore, $\mathrm{Ml} \mathrm{EtOAcF}$ and $\mathrm{Ml} \mathrm{EtOH}-\mathrm{H}_{2} \mathrm{OE}$ displayed a potent inhibition against Bacillus sp., L. monocytogenes, and S. enteritidis with an MIC that ranged from 39 to 156 $\mu \mathrm{g} / \mathrm{ml}$. Infections caused by these bacteria, especially those with multidrugs resistance, are among the most difficult to treat with conventional antibiotics. In the current study, the growth of $B$. subtilis was remarkably inhibited by the $\mathrm{Ml} \mathrm{EtOAcF}(\mathrm{IZ}=27 \mathrm{~mm}$; $\mathrm{MIC}=0.039 \mathrm{mg} / \mathrm{ml}$; and $\mathrm{MBC}$ $=0.078 \mathrm{mg} / \mathrm{ml})$. The $\mathrm{Ml}$ EtOAcF remarkable antibacterial activity could be mainly due to its richness in composites that are well known by their antibacterial properties such as polyphenols and flavonoids found abundantly in this fraction [58]. Previous studies reported that these compounds are therefore able to minimize problems of drug resistance [59]. Earlier reports demonstrated that an interaction between signal transduction pathways and cell receptors and chemicals like polyphenols leads to the interruption of microorganisms growth and results in the cell death [60]. These results revealed that $\mathrm{Ml} \mathrm{EtOAcF}$ can be used to manage bacterial resistance and protect foods against multiple pathogenic bacteria. 
TABLE 4: Season variation in antibacterial activity of $M$. longifolia essential oils against the bacterial strains tested. $\mathrm{EO}_{\mathbf{w}}$ : essential oil extracted at winter season; $\mathrm{EO}_{\mathrm{s}}$ : spring essential oil.

(a)

\begin{tabular}{|c|c|c|c|c|c|}
\hline \multirow{2}{*}{ Bacterial strains } & \multicolumn{4}{|c|}{ Extracts } & \multirow[b]{2}{*}{ Genta $^{*}$} \\
\hline & Ml EtOcF & $\begin{array}{c}\mathrm{Ml} \\
\text { EtOH-H2 }\end{array}$ & $\mathrm{EO}_{\mathrm{w}}$ & $\mathrm{EO}_{\mathrm{s}}$ & \\
\hline \multicolumn{6}{|c|}{ Diameter of inhibition zone (mm) } \\
\hline \multicolumn{6}{|l|}{ Gram $^{+}$} \\
\hline $\begin{array}{l}\text { B. subtilis } \\
\text { ATCC } 6633\end{array}$ & $27 \pm 0.1^{\mathrm{a}}$ & $14 \pm 0.2^{\mathrm{c}}$ & $26.3 \pm 0.0^{\mathrm{a}}$ & $11 \pm 0.5^{\mathrm{d}}$ & $20 \pm 0.2^{\mathrm{b}}$ \\
\hline $\begin{array}{l}\text { B. cereus } \\
\text { ATCC } 14579\end{array}$ & $17 \pm 0.3^{c}$ & $12 \pm 0.8^{\mathrm{e}}$ & $26 \pm 0.2^{\mathrm{a}}$ & $14 \pm 0.6^{\mathrm{d}}$ & $20 \pm 0.4^{\mathrm{b}}$ \\
\hline $\begin{array}{l}\text { S. aureus } \\
\text { ATCC } 25923\end{array}$ & $25 \pm 0.0^{\mathrm{a}}$ & $13 \pm 0.6^{b}$ & $24.9 \pm 0.3^{\mathrm{a}}$ & $14.6 \pm 0.5^{\mathrm{b}}$ & $25 \pm 0.8^{\mathrm{a}}$ \\
\hline $\begin{array}{l}\text { S. epidemis } \\
\text { ATCC } 12228\end{array}$ & $24 \pm 0.6^{\mathrm{a}}$ & $20 \pm 0.3^{b}$ & $14 \pm 0.4^{c}$ & $13 \pm 0.0^{c}$ & $20 \pm 0.5^{\mathrm{b}}$ \\
\hline $\begin{array}{l}\text { E. faecalis } \\
\text { ATCC } 29212\end{array}$ & $18 \pm 0.1^{b}$ & $0^{\mathrm{d}}$ & $20 \pm 0.3^{\mathrm{a}}$ & $12 \pm 0.1^{\mathrm{c}}$ & $12 \pm 0.2^{\mathrm{c}}$ \\
\hline $\begin{array}{l}\text { M. luteus } \\
\text { ATCC } 1880\end{array}$ & $21 \pm 0.4^{\mathrm{a}}$ & $18 \pm 0.5^{\mathrm{b}}$ & $15 \pm 0.6^{c}$ & $15 \pm 0.6^{c}$ & $20 \pm 0.7^{\mathrm{a}}$ \\
\hline $\begin{array}{l}\text { L. monocytogenes } \\
\text { (food isolate } 2132 \text { ) }\end{array}$ & $19 \pm 0.2^{\mathrm{a}}$ & $18 \pm 0.1^{\mathrm{a}}$ & $13.16 \pm 0.4^{c}$ & $12.60 \pm 0.9^{c}$ & $15 \pm 0.0^{\mathrm{b}}$ \\
\hline \multicolumn{6}{|l|}{$\mathrm{Gram}^{-}$} \\
\hline $\begin{array}{l}\text { S. enteritidis } \\
\text { (food isolate) }\end{array}$ & $24 \pm 0.2^{\mathrm{a}}$ & $14 \pm 0.3^{c}$ & $10 \pm 0.12^{\mathrm{d}}$ & $11.3 \pm 0.1^{\mathrm{d}}$ & $18 \pm 0.8^{\mathrm{b}}$ \\
\hline $\begin{array}{l}\text { K. pneumoniae } \\
\text { ATCC } 10031\end{array}$ & $18 \pm 0.2^{\mathrm{a}}$ & $15 \pm 0.1^{\mathrm{c}}$ & $16.6 \pm 0.3^{b}$ & $16 \pm 0.5^{\mathrm{bc}}$ & $12 \pm 0.5^{\mathrm{d}}$ \\
\hline
\end{tabular}

(b)

\begin{tabular}{|c|c|c|c|c|c|c|c|c|c|}
\hline \multicolumn{10}{|c|}{ Minimum inhibitory concentrations (MIC) and Minimum bactericidal concentration (MBC) (mg/ml) } \\
\hline & MIC & MBC & MIC & MBC & MIC & MBC & MIC & MBC & \\
\hline \multicolumn{10}{|l|}{$\mathrm{Gram}^{+}$} \\
\hline $\begin{array}{l}\text { B. subtilis } \\
\text { ATCC } 6633\end{array}$ & 0.039 & 0.078 & 0.078 & 0.156 & 0.078 & 5.0 & 0.156 & 5.0 & - \\
\hline $\begin{array}{l}\text { B. cereus } \\
\text { ATCC } 14579\end{array}$ & 0.039 & 0.625 & 0.156 & 5.0 & 0.156 & 0.156 & 0.312 & 5.0 & - \\
\hline $\begin{array}{l}\text { S. aureus } \\
\text { ATCC } 25923\end{array}$ & 0.625 & 1.25 & 2.5 & 5.0 & 0.312 & 0.625 & 0.625 & 0.625 & - \\
\hline $\begin{array}{l}\text { S. epidemis } \\
\text { ATCC } 12228\end{array}$ & 0.156 & 0.312 & 2.5 & 2.5 & 5.0 & 10 & 5.0 & 10 & - \\
\hline $\begin{array}{l}\text { E. faecalis } \\
\text { ATCC } 29212\end{array}$ & 1.25 & 1.25 & 2.5 & 2.5 & 0.078 & 1.25 & 0.625 & 10 & - \\
\hline $\begin{array}{l}\text { M. luteus } \\
\text { ATCC } 1880\end{array}$ & 0.312 & 1.25 & 2.5 & 5.0 & 5.0 & 10 & 5.0 & 10 & - \\
\hline $\begin{array}{l}\text { L. monocytogenes } \\
\text { (food isolate } 2132 \text { ) }\end{array}$ & 0.156 & 0.625 & 2.5 & 5.0 & 1.25 & 5.0 & 1.25 & 5.0 & - \\
\hline \multicolumn{10}{|l|}{$\mathrm{Gram}^{-}$} \\
\hline $\begin{array}{l}\text { S. enteritidis } \\
\text { (food isolate) }\end{array}$ & 0.078 & 0.625 & 0.312 & 5.0 & 2.5 & 5.0 & 2.5 & 5.0 & - \\
\hline $\begin{array}{l}\text { K. pneumoniae } \\
\text { ATCC } 10031\end{array}$ & 0.312 & 1.25 & 0.312 & 5.0 & 2.5 & 2.5 & 2.5 & 2.5 & - \\
\hline
\end{tabular}

${ }^{*}$ Genta: gentamicin was used as a standard antibiotic at a concentration of $15 \mu \mathrm{g} /$ well; essential oil concentration: $15 \mu \mathrm{l} /$ well; extract concentration: $2.5 \mathrm{mg} / \mathrm{ml}$. $(-)$ : not active $(0 \mathrm{~mm})$.

Values in the same line with different subscript $(\mathrm{a}>\mathrm{b}>\mathrm{c}>\mathrm{d})$ are significantly different within season $(P<0.05)$. 


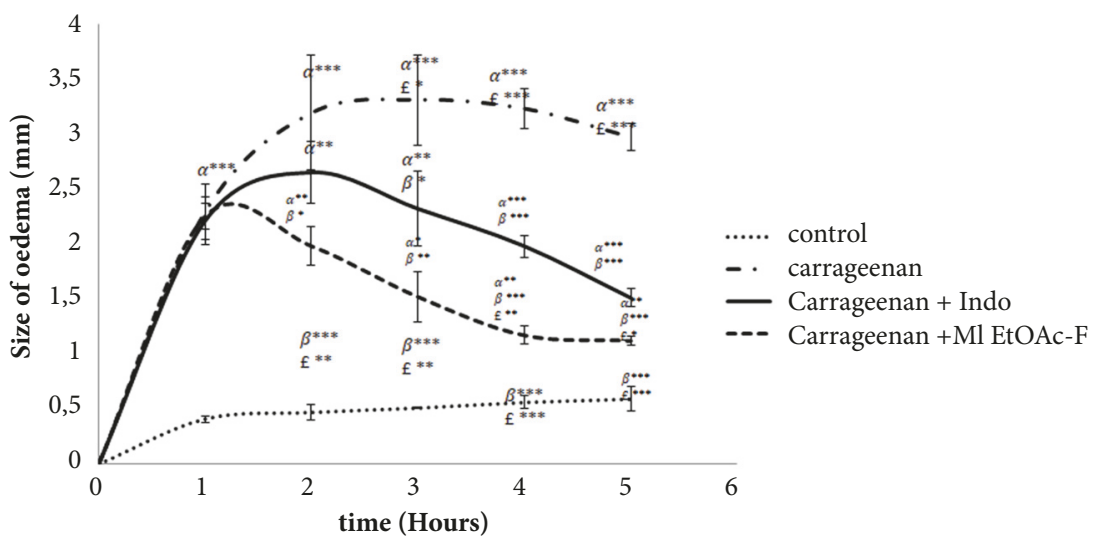

FIGURE 1: Effect of $\mathrm{Ml} \mathrm{EtOcF}$ and indomethacin on paw oedema induced by carrageenan. Values represent mean $\pm \mathrm{SD}(n=6)$ in each group. $* P<0.05, * * P<0.01$, and $* * * P<0.001$. $\alpha$ : compared to control; $\beta$ : compared to Carr; $£$ : compared to Carr + Indo. Control: saline solution, Carr: carrageenan, Carr $+\mathrm{Ml} \mathrm{EtOcF}$ : carrageenan + M. longifolia ethyl acetate fraction; Carr + Indo: carrageenan + indomethacin.

According to its strong antibacterial and antioxidant activities, the $\mathrm{Ml} \mathrm{EtOAcF}$ was chosen to be evaluated for its anti-inflammatory efficiency in rats' models.

3.6. Acute Toxicity Study. The Ml EtOAcF up to the dose of $800 \mathrm{mg} / \mathrm{kg}$ BW did not produce any signs of adverse reactions and no changes on the behavior of the treated animals up to 14 days following the extract administration. The treated animals did not display any abnormal signs such as food and water intake, convulsions, salivation, or diarrhea. No deaths or weight losses were recorded during the study. Therefore, the $\mathrm{Ml} \mathrm{EtOAcF}$ at $200 \mathrm{mg} / \mathrm{Kg} \mathrm{BW}$ was used in the in vivo investigation of the anti-inflammatory activity.

3.7. Anti-Inflammatory Activity. In our study, subcutaneous administration of carrageenan induced an increase in paw size in rats due to oedema, thus revealing an acute paw inflammation. Figure 1 shows the paw thickness in the different studied groups. The $\mathrm{Ml} \mathrm{EtOAcF}$ and indomethacin significantly reduced carrageenan induced paw oedema in rats $(P<0.001)$ five hours after the induction of inflammation when compared to the control group.

Our findings revealed an inhibition of $62.29 \%$ of the paw oedema using the $\mathrm{Ml} \mathrm{EtOAcF}$ compared to only $49.15 \%$ inhibition using the standard drug indomethacin after five hours $(P<0.01)$. The anti-inflammatory effect of $200 \mathrm{mg} / \mathrm{kg}$ BW of Ml EtOAcF was comparable to that of the standard drug indomethacin (Figure 1).

The paw oedema tissues from all the groups were histologically examined (Figure 2). The control group showed normal tissue whereas the carrageenan inflamed group displayed an intense oedema, characterized by conjunctive tissue with a substantial number of inflammatory cells infiltration. The carrageenan groups pretreated with indomethacin $(10 \mathrm{mg} / \mathrm{kg})$ or $\mathrm{Ml} \mathrm{EtOAcF}(200 \mathrm{mg} / \mathrm{kg})$ exhibited a significant decrease in oedema as well as reduction in the inflammatory cells (Figure 2).

The development of oedema inflammation is a biphasic event: the first phase is caused by the release of histamine, leukotrienes, bradykinin, and cyclooxygenases in the first hour of the injection of carrageenan, and the second phase is linked to an increased generation of prostaglandins in the inflammatory tissue [61]. In the present study, Ml EtOAcF significantly improved the paw oedema induced by carrageenan after 5 hours. This result suggests that the Ml EtOAcF anti-inflammatory efficacy may be due to the inhibition of cyclooxygenase synthesis. Such an effect is similar to that produced by nonsteroidal anti-inflammatory drugs such as indomethacin [62]. However, the exact mechanism of how $\mathrm{Ml}$ EtOAcF inhibits cyclooxygenase biosynthesis could be part of our future perspectives.

\section{Conclusion}

The study highlighted the effect of the harvesting time on the essential oils composition and biological activities of M. longifolia. The essential oils extracted from the fresh leaves were characterized by their richness in oxygenated monoterpenes. Significant variations of the essential oils composition were shown depending on the harvesting time. M. longifolia essential oils have a remarkable antibacterial activity and an effective inhibitory effect against the enzyme related to Alzheimer's (AChE). However, the levels of these biological activities vary according to the harvest time. In fact, the interesting antibacterial and AChE inhibitory activities were observed in the winter crops, corresponding to the flowering stage. These results may be useful in choosing the optimal collection time for the production of the plant active agents with high medicinal value. The present study also revealed that the $\mathrm{Ml} \mathrm{EtOAcF}$ obtained from winter leaves has a significant anti-inflammatory capacity and the uppermost anticholinesterase activity. The richness of the extract in various chemicals such as phenolic compounds could clearly contribute to its medicinal properties. Further studies are still recommended to accurately identify the bioactive molecules in this extract for the exploitation of this plant in various pharmaceutical fields and the promotion of the desired biological activities. 


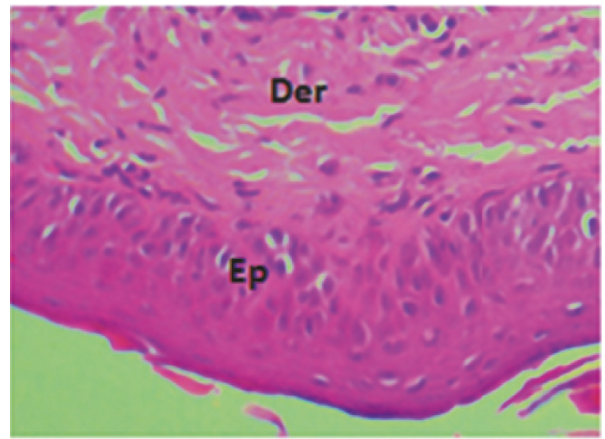

(a)

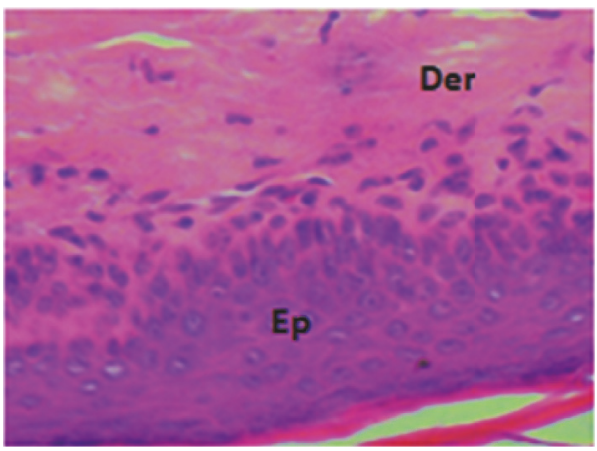

(c)

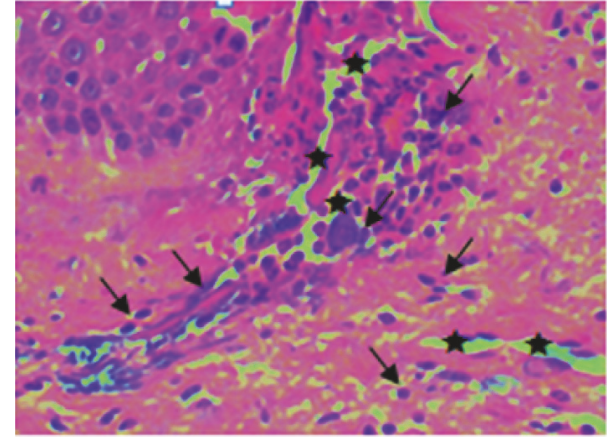

(b)

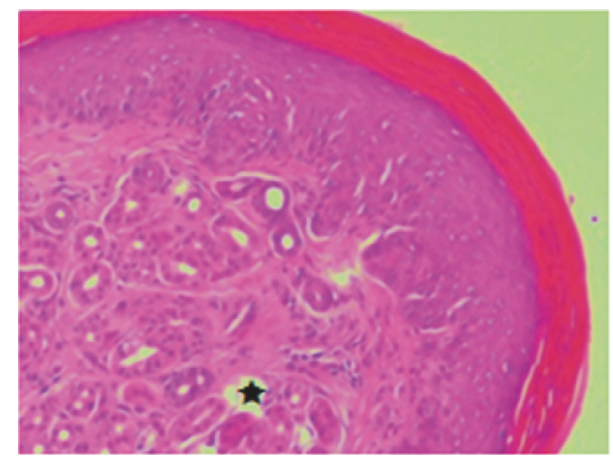

(d)

FIgURE 2: Histopathological slides tissues of oedema paws in experimental groups of rats: (a) Saline group; (b) Carr group; (c) Carr + Ml EtOcF group (200 mg BW); (d) Carr + Indo group. Controls (a), rats treated with carrageenan (b), the combination of carrageenan and indomethacin (c), and treated rats with the combination of carrageenan and Ml EtOcF (d). Ep: epidermis; Der: dermis. Oedema $\star$. Inflammatory cell $\nearrow$.

\section{Data Availability}

No data were used to support this study.

\section{Conflicts of Interest}

The authors have declared that there are no conflicts of interest.

\section{Acknowledgments}

This work was supported by grants from the Tunisian "Ministry of Higher Education and Scientific Research".

\section{References}

[1] W. Huang, X. Zhang, and W. Chen, "Role of oxidative stress in Alzheimer's disease," Biomedical Reports, vol. 4, no. 5, pp. 519$522,2016$.

[2] V. Lobo, A. Patil, A. Phatak, and N. Chandra, "Free radicals, antioxidants and functional foods: impact on human health," Pharmacognosy Reviews, vol. 4, no. 8, pp. 118-126, 2010.

[3] M. B. Pisano, S. Cosentino, S. Viale et al., "Biological activities of aerial parts extracts of euphorbia characias," BioMed Research International, vol. 2016, 11 pages, 2016.
[4] K. W. Kong, S. Mat-Junit, N. Aminudin, F. A. Hassan, A. Ismail, and A. A. Aziz, "Protective effects of the extracts of Barringtonia racemosa shoots against oxidative damage in HepG2 cells," PeerJ, vol. 4, article e1628, 2016.

[5] P. Arulselvan, M. T. Fard, W. S. Tan et al., "Role of antioxidants and natural products in inflammation," Oxidative Medicine and Cellular Longevity, vol. 2016, Article ID 5276130, 15 pages, 2016.

[6] A. S. Ravipati, L. Zhang, S. R. Koyyalamudi et al., "Antioxidant and anti-inflammatory activities of selected Chinese medicinal plants and their relation with antioxidant content," BMC Complementary and Alternative Medicine, vol. 12, article 173, 2012.

[7] S. Li, G. Chen, C. Zhang, M. Wu, S. Wu, and Q. Liu, "Research progress of natural antioxidants in foods for the treatment of diseases," Food Science and Human Wellness, vol. 3, no. 3-4, pp. 110-116, 2014.

[8] K. B. Pandey and S. I. Rizvi, "Plant polyphenols as dietary antioxidants in human health and disease," Oxidative Medicine and Cellular Longevity, vol. 2, Article ID 897484, 9 pages, 2009.

[9] D.-Y. Choi, Y.-J. Lee, J. T. Hong, and H.-J. Lee, “Antioxidant properties of natural polyphenols and their therapeutic potentials for Alzheimer's disease," Brain Research Bulletin, vol. 87, no. 2-3, pp. 144-153, 2012.

[10] R. M. Lane, S. G. Potkin, and A. Enz, "Targeting acetylcholinesterase and butyrylcholinesterase in dementia," The International Journal of Neuropsychopharmacology, vol. 9, no. 1, pp. 101-124, 2006. 
[11] A. P. Murray, M. B. Faraoni, M. J. Castro, N. P. Alza, and V. Cavallaro, "Natural AChE inhibitors from plants and their contribution to Alzheimer's disease therapy," Current Neuropharmacology, vol. 11, no. 4, pp. 388-413, 2013.

[12] F. Naghibi, M. Mosaddegh, M. M. Motamed, and A. Ghorbani, "Labiatae family in folk medicine in Iran: from ethnobotany to pharmacology," Iranian Journal of Pharmaceutical Research, pp. 63-79, 2010.

[13] N. Mimica-Dukić, B. Božin, M. Soković, B. Mihajlović, and M. Matavulj, "Antimicrobial and antioxidant activities of three Mentha species essential oils," Planta Medica, vol. 69, no. 5, pp. 413-419, 2003.

[14] A. M. Damic, M. S. Sokovic, M. Novakovic, S. Grujic-Jovanovic, V. Teevic, and P. D. Marin, "Antifungal and antioxidant activity of Mentha longifolia (L.) Hudson (Lamiaceae) essential oil," Botanica Serbica, vol. 34, no. 5, pp. 57-61, 2010.

[15] M. A. Ebrahimzadeh, S. M. Nabavi, and S. F. Nabavi, "Antioxidant and antihemolytic activities of Mentha longifolia," Pharmacologyonline, vol. 2, pp. 464-471, 2010.

[16] A. J. Kirby and R. J. Schmidt, "The antioxidant activity of Chinese herbs for eczema and of placebo herbs - I," Journal of Ethnopharmacology, vol. 56, no. 2, pp. 103-108, 1997.

[17] C. Quettier-Deleu, B. Gressier, J. Vasseur et al., "Phenolic compounds and antioxidant activities of buckwheat (Fagopyrum esculentum Moench) hulls and flour," Journal of Ethnopharmacology, vol. 72, no. 1-2, pp. 35-42, 2000.

[18] M. Trigui, A. B. Hsouna, S. Tounsi, and S. Jaoua, "Chemical composition and evaluation of antioxidant and antimicrobial activities of Tunisian Thymelaea hirsuta with special reference to its mode of action," Industrial Crops and Products, vol. 41, no. 1, pp. 150-157, 2013.

[19] K. Güven, E. Yücel, and F. Cetintaş, "Antimicrobial activities of fruits of Crataegus and Pyrus species," Pharmaceutical Biology, vol. 44, no. 2, pp. 79-83, 2006.

[20] J. N. Eloff, "A sensitive and quick microplate method to determine the minimal inhibitory concentration of plant extracts for bacteria," Planta Medica, vol. 64, no. 8, pp. 711-713, 1998.

[21] A. T. Mata, C. Proença, A. R. Ferreira, M. L. M. Serralheiro, J. M. F. Nogueira, and M. E. M. Araújo, "Antioxidant and antiacetylcholinesterase activities of five plants used as Portuguese food spices," Food Chemistry, vol. 103, no. 3, pp. 778-786, 2007.

[22] M. Sefi, H. Fetoui, N. Soudani, Y. Chtourou, M. Makni, and N. Zeghal, "Artemisia campestris leaf extract alleviates early diabetic nephropathy in rats by inhibiting protein oxidation and nitric oxide end products," Pathology - Research and Practice, vol. 208, no. 3, pp. 157-162, 2012.

[23] E. A. Winter, E. A. Risley, and G. W. Nuss, "Carrageenan induced paw edema in hind paw as an assay for antiinflammatory drugs," Journal of Pharmacology and Experimental Therapeutics, vol. 141, pp. 369-373, 1963.

[24] J.-C. Liao, J.-S. Deng, C.-S. Chiu et al., "Anti-inflammatory activities of Cinnamomum cassia constituents in vitro and in vivo," Evidence-Based Complementary and Alternative Medicine, vol. 2012, Article ID 429320, 12 pages, 2012.

[25] A. R. Golparvar, A. Hadipanah, and A. M. Mehrabi, "Effect of phenological stage on yield, essential oil and thymol percentage of Thymus daenensis grown in Iran," Indian Journal of Fundamental and Applied Life Sciences, vol. 5, no. 1, pp. 2903-2910, 2015.

[26] G. Kofidis, A. Bosabalidis, and S. Kokkini, "Seasonal variation of essential oils in a linalool-rich chemotype of mentha spicata grown wild in greece)," Journal of Essential Oil Research, vol. 16, no. 5, pp. 469-472, 2004.

[27] A. I. Hussain, F. Anwar, P. S. Nigam, M. Ashraf, and A. H. Gilani, "Seasonal variation in content, chemical composition and antimicrobial and cytotoxic activities of essential oils from four mentha species," Journal of the Science of Food and Agriculture, vol. 90, no. 11, pp. 1827-1836, 2010.

[28] J. Valmorbida, C. F. S. Boaro, M. O. M. Marques, and A. F. Ferri, "Rendimento e composição química de óleos essenciais de Mentha piperita L. cultivada em solução nutritiva com diferentes concentrações de potássio," Revista Brasileira de Plantas Medicinais, vol. 8, pp. 56-61, 2006.

[29] A. C. Figueiredo, J. G. Barroso, L. G. Pedro, and J. J. C. Scheffer, "Factors affecting secondary metabolite production in plants: volatile components and essential oils," Flavour and Fragrance Journal, vol. 23, no. 4, pp. 213-226, 2008.

[30] A. I. Hussain, F. Anwar, S. T. Hussain Sherazi, and R. Przybylski, "Chemical composition, antioxidant and antimicrobial activities of basil (Ocimum basilicum) essential oils depends on seasonal variations," Food Chemistry, vol. 108, no. 3, pp. $986-$ 995, 2008.

[31] Z. C. Gazim, A. C. L. Amorim, A. M. C. Hovell et al., "Seasonal variation, chemical composition, and analgesic and antimicrobial activities of the essential oil from leaves of Tetradenia riparia (Hochst.) Cdd in suthern Brazil," Molecules, vol. 15, no. 8, pp. 5509-5524, 2010.

[32] V. Masotti, F. Juteau, J. M. Bessière, and J. Viano, "Seasonal and phenological variations of the essential oil from the narrow endemic species Artemisia molinieri and its biological activities," Journal of Agricultural and Food Chemistry, vol. 51, no. 24, pp. 7115-7121, 2003.

[33] O. T. Asekun, D. S. Grierson, and A. J. Afolayan, "Effects of drying methods on the quality and quantity of the essential oil of Mentha longifolia L. subsp. Capensis," Food Chemistry, vol. 101, no. 3, pp. 995-998, 2006.

[34] S. Ghoulami, A. Il Idrissi, and S. Fkih-Tetouani, "Phytochemical study of Mentha longifolia of Morocco," Fitoterapia, vol. 72, no. 5, pp. 596-598, 2001.

[35] G. J. Amabeoku, S. J. Erasmus, J. A. O. Ojewole, and J. T. Mukinda, "Antipyretic and antinociceptive properties of Mentha longifolia Huds. (lamiaceae) leaf aqueous extract in rats and mice," Methods and Findings in Experimental and Clinical Pharmacology, vol. 31, no. 10, pp. 645-649, 2009.

[36] M. Alothman, R. Bhat, and A. A. Karim, "Antioxidant capacity and phenolic content of selected tropical fruits from Malaysia, extracted with different solvents," Food Chemistry, vol. 115, no. 3, pp. 785-788, 2009.

[37] D. Mhalla, A. Bouaziz, K. Ennouri et al., "Antimicrobial activity and bioguided fractionation of Rumex tingitanus extracts for meat preservation," Meat Science, vol. 125, pp. 22-29, 2017.

[38] S. Vladimir-Knezevic, B. Blazekovic, M. Kindl, J. Vladic, A. D. Lower-Nedza, and A. H. Brantner, "Acetylcholinesterase inhibitory, antioxidant and phytochemical properties of selected medicinal plants of the lamiaceae family," Molecules, vol. 19, no. 1, pp. 767-782, 2014.

[39] W. Dhifi, S. Bellili, S. Jazi, N. Bahloul, and W. Mnif, "Essential oils' chemical characterization and investigation of some biological activities: a critical review," Medicines, vol. 3, no. 4, pp. 25-31, 2016.

[40] S. U. Savelev, E. J. Okello, and E. K. Perry, "Butyryl- and acetylcholinesterase inhibitory activities in essential oils of salvia 
species and their constituents," Phytotherapy Research, vol. 18, no. 4, pp. 315-324, 2004.

[41] M. Miyazawa, H. Watanabe, K. Umemoto, and H. Kameoka, "Inhibition of acetylcholinesterase activity by essential oils of Mentha species," Journal of Agricultural and Food Chemistry, vol. 46, no. 9, pp. 3431-3434, 1998.

[42] V. López, S. Martín, M. P. Gómez-Serranillos, M. E. Carretero, A. K. Jäger, and M. I. Calvo, "Neuroprotective and neurochemical properties of mint extracts," Phytotherapy Research, vol. 24, no. 6, pp. 869-874, 2010.

[43] E. K. Perry, A. T. Pickering, W. W. Wang, P. J. Houghton, and N. S. L. Perry, "Medicinal plants and Alzheimer's disease: from ethnobotany to phytotherapy," Journal of Pharmacy and Pharmacology, vol. 51, no. 5, pp. 527-534, 1999.

[44] P. K. Mukherjee, V. Kumar, M. Mal, and P. J. Houghton, "Acetylcholinesterase inhibitors from plants," Phytomedicine, vol. 14, no. 4, pp. 289-300, 2007.

[45] M. Heinrich and H. L. Teoh, "Galanthamine from snowdropthe development of a modern drug against Alzheimer's disease from local Caucasian knowledge," Journal of Ethnopharmacology, vol. 92, no. 2-3, pp. 147-162, 2004.

[46] N. T. J. Tildesley, D. O. Kennedy, E. K. Perry et al., "Salvia lavandulaefolia (Spanish Sage) enhances memory in healthy young volunteers," Pharmacology Biochemistry \& Behavior, vol. 75, no. 3, pp. 669-674, 2003.

[47] P.J. Houghton, Y. Ren, and M. Howes, "Acetylcholinesterase inhibitors from plants and fungi," Natural Product Reports, vol. 23, pp. 181-199, 2006.

[48] M. Gulluce, F. Sahin, M. Sokmen et al., "Antimicrobial and antioxidant properties of the essential oils and methanol extract from Mentha longifolia L. ssp. longifolia," Food Chemistry, vol. 103, no. 4, pp. 1449-1456, 2007.

[49] M. Mkaddem, J. Bouajila, M. Ennajar, A. Lebrihi, F. Mathieu, and M. Romdhane, "Chemical composition and antimicrobial and antioxidant activities of mentha (longifolia L. and viridis) essential oils," Journal of Food Science, vol. 74, no. 7, pp. M358M363, 2009.

[50] H. Hajlaoui, N. Trabelsi, E. Noumi et al., "Biological activities of the essential oils and methanol extract of tow cultivated mint species (Mentha longifolia and Mentha pulegium) used in the Tunisian folkloric medicine," World Journal of Microbiology and Biotechnology, vol. 25, no. 12, pp. 2227-2238, 2009.

[51] G. Flamini, P. L. Cioni, R. Puleio, I. Morelli, and L. Panizzi, "Antimicrobial activity of the essential oil of Calamintha nepeta and its constituent pulegone against bacteria and fungi," Phytotherapy Research, vol. 13, no. 4, pp. 349-351, 1999.

[52] B. Marinkovié, P. D. Marin, J. Knezevié-Vukcevié, M. Sokovié, and D. Brkié, "Activity of essential oils of three Mieromeria species (Lamiaeeae) against micromycetes and bacteria," Phytotherapy Research, vol. 16, no. 4, pp. 336-339, 2002.

[53] A. Sonboli, M. H. Mirjalili, J. Hadian, S. N. Ebrahimi, and M. Yousefzadi, "Antibacterial activity and composition of the essential oil of Ziziphora clinopodioides subsp. bungeana (Juz.) Rech. f. from Iran," Zeitschrift fur Naturforschung - Section C Journal of Biosciences, vol. 61, no. 9-10, pp. 677-680, 2006.

[54] L. Li, Z.-W. Li, Z.-Q. Yin et al., "Antibacterial activity of leaf essential oil and its constituents from Cinnamomum longepaniculatum," International Journal of Clinical and Experimental Medicine, vol. 7, no. 7, pp. 1721-1727, 2014.

[55] M. Simsek and R. Duman, "Investigation of effect of 1,8cineole on antimicrobial activity of chlorhexidine gluconate," Pharmacognosy Research, vol. 9, no. 3, pp. 234-237, 2017.
[56] F. A. Oladimeji, L. O. Orafidiya, and I. N. Okeke, "Physical properties and antimicrobial activities of leaf essential oil of Lippia multiflora Moldenke," International Journal of Aromatherapy, vol. 14, no. 4, pp. 162-168, 2004.

[57] V. P. Kumar, N. S. Chauhan, H. Padh, and M. Rajani, "Search for antibacterial and antifungal agents from selected Indian medicinal plants," Journal of Ethnopharmacology, vol. 107, no. 2, pp. 182-188, 2006.

[58] V. M. Barbosa-Filho, E. P. Waczuk, N. F. Leite et al., "Phytocompounds and modulatory effects of anacardium microcarpum (cajui) on antibiotic drugs used in clinical infections," Drug Design, Development and Therapy, vol. 9, pp. 5965-5972, 2015.

[59] S. Gibbons, "Phytochemicals for bacterial resistance-strengths, weaknesses and opportunities," Planta Medica, vol. 74, no. 6, pp. 594-602, 2008.

[60] F. F. G. Rodrigues, J. G. M. Costa, and H. D. M. Coutinho, "Synergy effects of the antibiotics gentamicin and the essential oil of Croton zehntneri," Phytomedicine, vol. 16, no. 11, pp. 10521055, 2009.

[61] P. M. Brooks and R. O. Day, "Nonsteroidal antiinflammatory drugs: differences and similarities," The New England Journal of Medicine, vol. 324, no. 24, pp. 1716-1725, 1991.

[62] A. K. Gupta, D. Parasar, A. Sagar et al., "Analgesic and antiinflammatory properties of gelsolin in acetic acid induced writhing, tail immersion and carrageenan induced paw edema in mice," PLoS ONE, vol. 10, no. 8, 2015. 

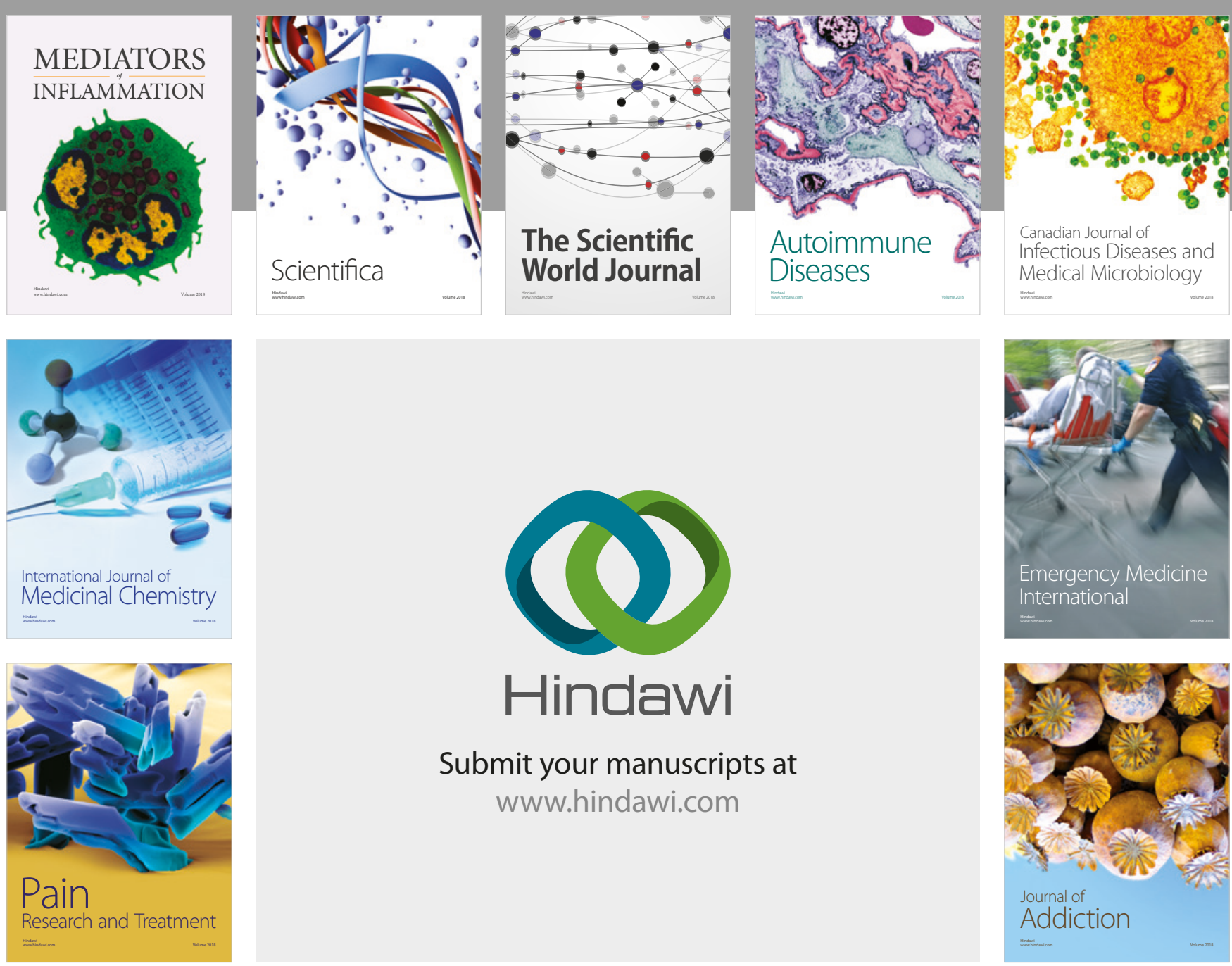

Canadian Journal of
Infectious Diseases and Medical Microbiology

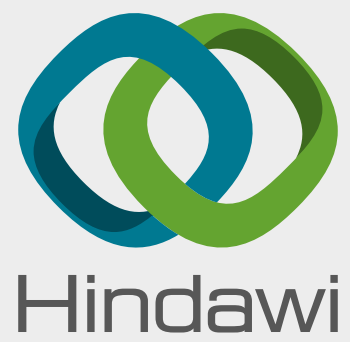

Submit your manuscripts at

www.hindawi.com
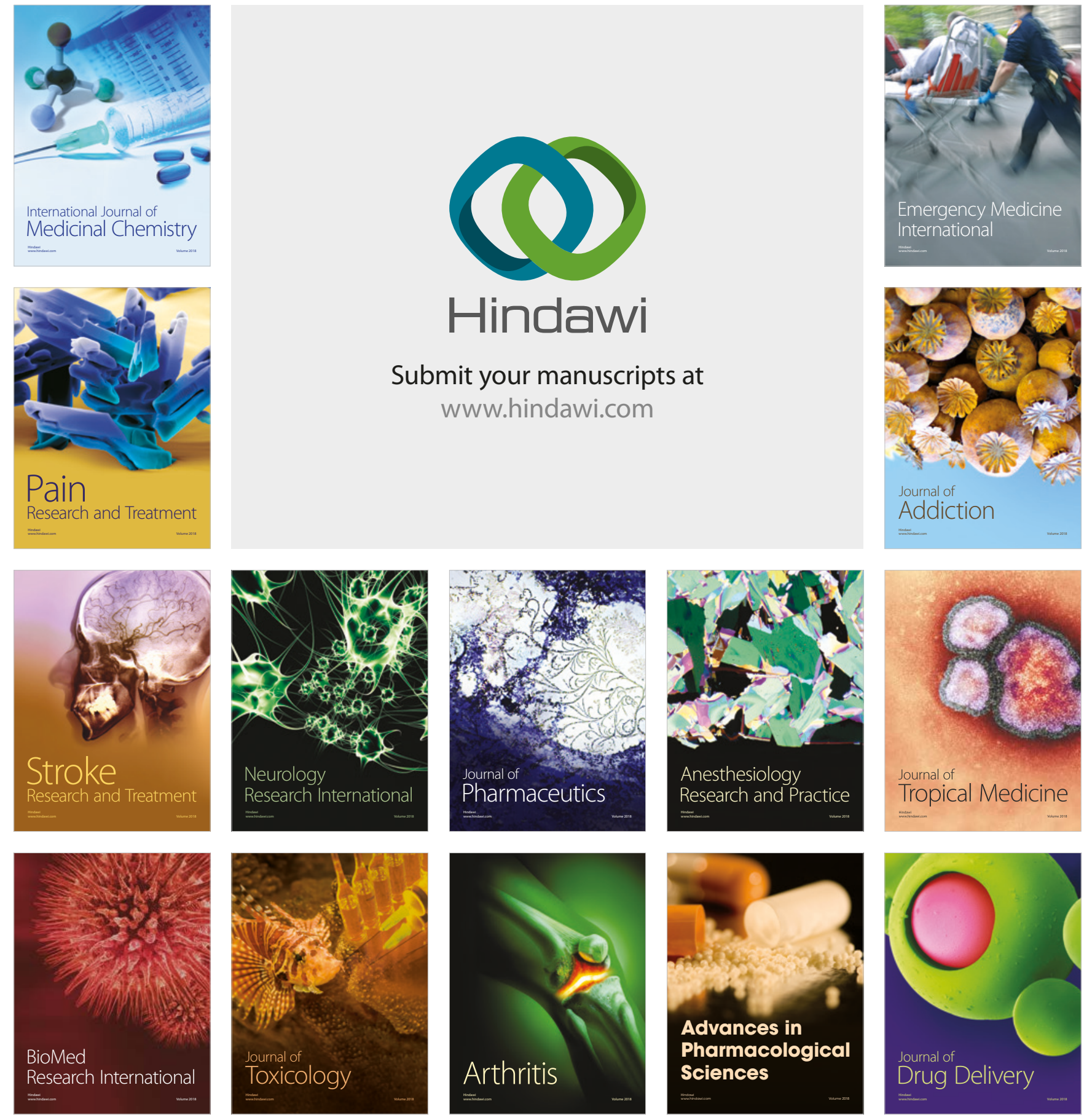